\title{
5 \\ The New Demand for Heterogeneity in College Teaching
}

George Keller

Baltimore, Maryland

The past half century has brought an astounding increase in U.S. college and university enrollments. The rapid rise of mass higher education has forced major changes at every institution and is reshaping the U.S. higher education enterprise. Each college needs to ask itself what the huge expansion means for future faculty hires, programs, and modes of teaching.

\section{Introduction}

Most persons in higher education are aware of the enormous enrollment growth at U.S. colleges and universities in the past half century. But relatively few have fully recognized the radical consequences of this evolution from elite higher education to mass higher education-for teaching, faculty hiring, and the structure of American higher education. Many persons, even scholars of higher learning, still write and speak of the enterprise of higher learning as if it were a unitary entity with only minor differences among the schools; or they advocate improvements in teaching or curriculum as if the improvements should be, or could be, fairly standardized across the nearly 4,000 nonprofit institutions.

But the American movement to make college available not just to a minority of the brightest, more affluent, and most ambitious youths, but to masses of youngsters-and adults-compels us to rethink some accepted postulates about tertiary education. We also need to become more knowledgeable about the numerous ways in which the nation's commitment to providing college education for all has been reshaping U.S. higher education. 
We cannot improve the academy wisely unless we understand the consequences that mass higher education has brought to the campuses.

\section{The Dimensions of Enrollment Growth}

It is difficult to comprehend the enormity of the growth of education in the United States during the past six decades. In 1940 only $25 \%$ of adult Americans had even a high school diploma. Twenty years later, in 1960, only $41 \%$ were high school graduates. Today $80 \%$ have completed high school. Similarly, in 1940 only a tiny minority went on to college, and in 1960 less than $8 \%$ of U.S. adults had college degrees. The now-huge University of California was then composed of only two major universities, a medical school and three undergraduate colleges. Today, however, America's 3,900 accredited colleges and universities enroll 15.3 million students. More than one-fourth of U.S. citizens 25 years or older now hold a college degree. The United States currently has double the college and university participation of most other countries, with only a few exceptions such as Norway.

Moreover, the composition of the students has changed. Since 1975 the number of students older than 35 has doubled, and the number of foreign students has quadrupled to roughly 580,000. There are many more women, African-Americans, Asians, and Latinos. Three in eight students now attend two-year colleges, where the learning tends to be largely vocational. More than 450,000 students, including many adults, are now enrolled in the newer for-profit colleges (National Center for Education Statistics, 2003). The overwhelming majority of the $\mathbf{1 5 . 3}$ million students are attending universities to prepare to become accountants, nurses, computer engineers, teachers, artists, technicians, and a host of other professions, semi-professions, and lines of work. Most of these persons are not bookish, deeply curious young intellectuals.

A great number of undergraduates, even some without talent, discipline, or ambition, are enrolled today because they are pushed and pulled to attend college, so they tend to be time-servers. Nearly half of all undergraduates drop out before completing their work for a degree. A growing number of students see little use in the liberal arts and are hostile to required courses in these subjects. They want courses that are "relevant," not those that explore Aristotle's philosophy, Giotto's or Rembrandt's paintings, plays by Shakespeare or books by Jane Austen or Alice Munro, poems by Keats or Yeats, texts by Adam Smith, Sigmund Freud, Reinhold Niebuhr, or Isaiah Berlin. A large number do not subscribe to the traditional values and purposes of higher 
education and demand instead that the professors teach to meet their needs and interests rather than teaching what the scholars think is best.

The first person to notice the radical implications of mass higher education was Berkeley sociologist Martin Trow, who, in two brilliant articles in the early 1970s, predicted that admitting millions of additional young persons with varying degrees of preparation and ambition would necessitate a restructuring of higher learning in America.

There is a fraction of youth that can achieve its adult roles and intrinsic satisfactions through prolonged formal study. That proportion may be 10,15 , or even 20 percent of the age-grade. But I am sure it is not 50 or 60 or 70 percent of the age-grade. That reason is enough to believe that the future of higher education cannot be an extrapolation of past tendencies. (Trow, 1971, p. 45)

The United States has proudly moved from a relatively limited and elite higher education to a hugely enlarged system which enrolls unprecedented masses of young people and a rapidly growing number of working adults. The vast and far more heterogeneous cohort of college and university students has forced dozens of changes and innovations and several major transformations.

\section{The New Topography of Higher Education}

The offerings at our colleges have had to expand in variety as the enlarged number of students come with a broader array of interests. Dozens of new majors and degrees have been added in fields as diverse as communications, physical therapy, black studies, public relations, and art therapy. Sports have ballooned on campus, along with new majors in sports administration and leisure studies. The core curriculum has eroded and been replaced usually by a Chinese-menu list of courses to fulfill a diluted set of liberal arts requirements. Undergraduate programs have become less research oriented and study has become more experiential, with increased time away from the professors through travel abroad, internships, and cooperative programs with employers. Discourse on campus has changed and is sprinkled as never before with vilifcation, harassment charges, and political attacks. At some campuses, speech codes have been installed to curtail increasing obscenities and gross insults.

A consensus about the values, behavior, and functions of university life has melted. A growing number of faculty are children of the rebellious $1960 \mathrm{~s}$, 1970 s, and 1980 s, and see as their primary mission the transformation of 
society rather than the advance of knowledge and introduction of students to the complexities, tradeoffs, wonders, and mysteries of life and the physical world. So-called political correctness is reported to be rife among the faculty at numerous institutions. Like the students, the composition of professors has become more diverse. As one trio of scholars writes, "The extent to which the faculty's demographic profile has changed in very recent years is unprecedented" (Finkelstein, Seal, \& Schuster, 1998, p. xi).

To accommodate the increased breadth of courses and variety of students, the structure of academic appointments is being radically altered. As one of the leading experts on America's faculty recently noted,

In the year 2001 , only about one-quarter of new faculty appointments were to full-time tenure track positions (i.e., half were parttime and more than half of the remaining full-time positions were "off" the tenure track).... Less obvious (but no less widespread) have been attempts to re-specialize the full-time faculty role: that is, to create full-time positions that do not require the "integrated" (and costly) Humboldtian model, to a more functionally specialized model wherein full-time faculty are now hired as teaching-only or even lower division/introductory courses only; or in the natural sciences and the professions, research-or-clinical only... (Finkelstein, 2003, pp. 8, 12).

But perhaps the most significant result of the move into mass higher education has been the differentiation both within and among colleges and universities. Within and among the institutions, faculty and administrative leaders have introduced several structural elements to cope with the greater variety, backgrounds, levels of ability, and interests of the admitted students.

\section{Segmenting the Enterprise}

Within colleges and universities, the schools have had to stretch the range of their teaching and programs of learning. To cope with the less prepared and dedicated entrants, many universities have introduced front-end remedial (or developmental) programs-22\% of all freshmen in public colleges in 1995and ESL (English as a Second Language) courses for the tidal wave of immigrant youths. At the other end, many colleges and universities have opened honors programs for the best prepared and more ambitious students. Most institutions have also abandoned the common core curriculum and increased the number of undergraduate semi-professional and vocational programs 
and the kinds of master's degrees. Such changes allow the colleges to serve the greatly expanded gamut of student abilities, interests, and needs.

Among the American institutions of higher learning, the advance of mass higher education has pressed into being a new, four-tier order. There are now four basic kinds of colleges and universities, each with its own collection of students, faculty, curriculum, and function for society. The most frequently cited and most prestigious stratum is that of the several dozen research universities. These have become primarily research factories, the principal source of new ideas, scientific findings, and discoveries. It may be hard to believe, but in 1952 the mean SAT-Verbal score at Harvard was only 583. The so-called Ivy League universities, Stanford, and similar schools, had enrollments only slightly above those of other good colleges in academic ability. But beginning in the late 1950s and 1960s they transformed themselves into meritocratic institutions. By 1990 just 10 universities-the Ivies plus Stanford and Berkeley-gathered in 31\% of the country's students who scored in the 700s in their SAT-Verbal test (Cook \& Frank, 1993; Herrnstein \& Murray, 1994). The top 50 research universities, along with a dozen or so of the finest liberal arts colleges, now attract a huge share of the nation's most gifted and studious youth. These same institutions also recruit the most diligent and creative-and expensive-research scholars, and soak up a giant proportion of the federal and corporate research grants. With only a few exceptions, such as Columbia University, the undergraduate curriculum at these places has no core of required learning; methodology and theory are central concerns. Perhaps a third of the teaching of undergraduates at these prestigious houses of intellect is left to graduate students, adjunct instructors, and part-time academics. This tier often has excellent graduate programs and professional schools.

The second tier is that of the small liberal arts colleges, most of them private schools. These schools are often the snug "academical villages" that Thomas Jefferson envisioned, and they are the mainstays of liberal arts learning, exceptional teaching, and what is left of character development. Few have graduate programs of renown, although most of these 100 or so institutions have recently added master's programs and professional schools (Breneman, 1994). At several of the best endowed colleges, such as Amherst, Carleton, Pomona, Swarthmore, and Williams, the quality of student preparation and SAT test scores is on a par with those of the best research universities; but others mainly attract students who are reasonably strong, talented, and moderately affluent.

The third tier, and by far the largest in enrollments, prepares students largely for the world of work. In this layer is a polyglot array of state universi- 
ties and colleges, regional private colleges and universities, and the specialized colleges of technology, art, education, and business. This tier skillfully turns out accountants, nurses, school teachers, farm managers, electronics experts, and engineers, as well as future lawyers, business executives, and doctors. Athletics is a major activity at many of the larger public and private schools. The faculty is usually a mix of research scholars, good teachers, specialists in some area of work, and many part-time instructors.

The fourth kind is composed of the 1,800 public and private two-year colleges and the less well endowed private four-year colleges. These schools take in more than $90 \%$ of their applicants, including some who are woefully underprepared, and they enroll a large percentage of adults in both degree programs and continuing education courses. The faculty tend to be more practically oriented and are called to be instructors that can motivate students (Grubb \& Associates, 1999). At many places there is a faculty union. The curriculum is heavily vocational and frequently remedial, and many classes are held in the evenings and on Saturdays. The new for-profit colleges, which often use online delivery of courses to serve busy adults, also concentrate on training for work rather than the education of persons. Thus, as one leading economist of higher education, Duke University's Charles Clotfelter (1999), has observed, "As in other markets where large differences of quality exist, the market for U.S. college education is segmented, with students who are seeking admission to elite institutions, for example, rarely applying simultaneously to community colleges" (p. 5).

\section{Looking at Teaching With Fresh Eyes}

If this brief analysis of the new world of mass higher education is close to reality, I believe that academics and administrators need to adopt a far more differentiated view of effective teaching and learning. We cannot alter the scale and breadth of America's higher education services in such a massive way without altering our outlook, structures, and modes of teaching. Effective teaching at the large research universities will differ from that at the state colleges and from that of the premier liberal arts colleges with their smaller classes and seminars, their stress on the accomplishments of civilization over the centuries, and their preparation for life and leadership rather than education for academic posts or professional or career distinction. Mass higher education decreases the worth of general, across-the-field prescriptions. The variety of students attending colleges and universities is different from that of several decades ago. The faculty seem in considerable part more active and 
opinionated politically, and their hiring and roles on campus have changed. The curricula of yesteryear have mostly dissolved and new majors have blossomed. The structure of higher education, with its increasingly segmented tiers, has become more hierarchical, with more distinct national missions for each tier. Teaching and learning should therefore become more clientele-specific, more institution-specific.

To me, a major need is for the faculty, administrators, and trustees at each institution to undertake a deep and frank assessment of its tradition and culture, the nature of its students, the quality, style, and teaching skill of the faculty, and the programs of learning the institution offers. They need to ask: How has the college been changing in the face of the greater heterogeneity of today's students, the new generation of faculty members, and the expanded range of academic fields of inquiry, from molecular genetics and software engineering to Chicano and Muslim studies? How should it change? How should your professors teach now that computers, young people from other ethnicities and cultures, and a wider range of student preparations and ambitions are present?

I have recently written about one college that did look into its soul and transformed itself for the coming decades (Keller, 2004). The scrutiny seems to have paid off. In the mid-1990s, Elon University had the usual three-times-aweek meetings for courses, with instruction offered heavily through lectures and reading assignments. There were roughly 300 courses in the catalog, and the faculty members each taught four or five courses a semester, which the academic vice president keenly wished to reduce. Earlier, a faculty member, who was also the director of advising, had begun giving each entering student a Myers-Briggs Type Indicator test. She found that most of the students were not heavily studious and introverted but for the most part, energetic, extroverted, and interested in learning. Elon's clientele were middle-of-the-graduating-class persons who loved to do things rather than read about what others have done.

So, the academic vice president decided to institute engaged learning, with students actively researching, creating, traveling, and building in their studies and extracurricular activities. He cut nearly 150 courses and stretched the class meetings to four times a week, with the extra hour devoted to active learning projects. The faculty's teaching load was reduced to three courses a semester, and their salaries were increased. A cocurricular program that encouraged students to do community service, travel and study abroad, work as interns in national businesses, run campus programs and help make policy, and conduct undergraduate research was installed. Thus, the teaching at this college became more interactive and problem oriented, and more learning was done through hands-on work outside of classes and active engagement with real-life situations. The teaching matched the kind of students that the institution was 
attracting instead of trying to force them to adhere to an older liberal arts pattern of instruction that is more appropriate for the elite colleges.

Given the new size and scope of American higher education, the leaders of every campus really should reappraise the operation of their houses of intellect. And each college and university should tailor its strategies, admits, and hiring to the specific role it plays, or intends to play, in advanced education in America.

\section{References}

Breneman, D. W. (1994). Liberal arts colleges: Thriving, surviving, or endangered? Washington, DC: The Brookings Institution.

Clotfelter, C. T. (1999). The familiar but curious economics of higher education. Journal of Economic Perspectives, 13(1), 3-12.

Cook, P. J., \& Frank, R. H. (1993). The growing concentration of top students at elite schools. In C. T. Clotfelter \& M. Rothschild (Eds.), Studies of supply and demand in higher education (pp. 121-144). Chicago, IL: University of Chicago Press.

Finkelstein, M. J. (2003). The morphing of the American academic profession. Liberal Education, 89(4), 6-15.

Finkelstein, M. J., Seal, R. K., \& Schuster, J. H. (1998). The new academic generation: A profession in transition. Baltimore, MD: Johns Hopkins University Press.

Grubb, W. N., \& Associates. (1999). Honored but invisible: An inside look at teaching in community colleges. New York, NY: Routledge.

Herrnstein, R. J., \& Murray, C. (1994). The bell curve: Intelligence and class structure in American life. New York, NY: Free Press.

Keller, G. (2004). Transforming a college: The story of a little-known college's strategic climb to national distinction. Baltimore, MD: Johns Hopkins University Press.

National Center for Education Statistics. (2003). Digest of education statistics, 2002. Retrieved May 13, 2005, from http://nces.ed.gov/pubsearch/pubsinfo.asp ?pubid $=2003060$

Trow, M. (1970). Reflections on the transition from mass to universal higher education. Daedalus, 99, 1-42.

Trow, M. (1971). Admissions and the crisis in American higher education. In W. T. Furniss (Ed.), Higher education for everybody? Issues and implications (pp. 26-52). Washington, DC: American Council on Education. 